\title{
RANCANG BANGUN APLIKASI PENCARIAN RUTE TERPENDEK JASA KIRIMAN BARANG BERBASIS MOBILE DENGAN METODE ALGORITMA DIJKSTRA
}

\author{
Martin Nugroho Parapat ${ }^{1}$, Deddy Kusbianto ${ }^{2}$, Cahya Rahmad ${ }^{3}$ \\ ${ }^{1,2,3}$ Program Studi Teknik Informatika, Jurusan Teknologi Informasi, Politeknik Negeri Malang \\ 1martinugroho.p@gmail.com, ${ }^{2}$ deddykusbianto@gmail.com, ${ }^{3}$ cahya.rahmad@polinema.ac.id
}

\begin{abstract}
Abstrak
Proses pengiriman pada PT. Pos Indonesia saat ini masih ada kesulitan dalam pendataan sekaligus penentuan rute atau jarak kiriman, karena masih terjadinya surat atau dokumen dan barang yang akan dikirim kepada penerima tersebut melewati dari rute atau wilayah walaupun sudah disortir ketujuan masing-masing.Dari permasalahan diatas maka diperlukan sistem pencarian jalur terpendek untuk jasa pengiriman barang menggunakan metode algoritma dijkstra, metode yang cukup popular karena dapat menyelesaikan pencarian jalur terpendek dari satu ke semua simpul yang ada pada suatu graf bearah dengan bobot dan nilai tidak negatif.Dengan pembuatan aplikasi ini dapat membantu pegawai kurir PT. Pos Indonesia dalam menentukan jarak terpendek dan pendataan pengiriman tiap wilayah atau rute yang sudah ditentukan.
\end{abstract}

Kata kunci : PT. Pos Indonesia, Metode Algoritma Dijkstra

\section{Pendahuluan}

\subsection{Latar Belakang}

Di era globalisasi sampai saat ini, tidak dapat dipungkuri bahwa jasa pengiriman barang sangat dibutuhkan oleh masyarakat maupun organisasi atau perusahaan.Jasa pengiriman yang sering digunakan pada saat ini, seperti PT. Pos Indonesia, dll. Pengiriman barang berupa (surat atau dokumen, barang elektronik, dan bahan-bahan lainya) yang semakin bertambah, sehingga terjadinya penumpukan pengiriman yang dapat sedikit menghambat dalam proses pengiriman pada masyarakat. Maka dari itu sangat dibutuhkan langkah-langkah yang harus diambil dalam mempercepat proses pengeriman salah satunya dengan pengambilan rute jarak terpendek serta pendataan.

Proses pengiriman PT. Pos Indonesia sangat berperan penting pada pelayanan yang diberikan terhadap masyarakat karena sangat sering digunakan, namun ada beberapa proses yang akan dilakukan antara lain :

(a). surat yang masuk dari loket kemudian akan diserahkan kepada bagian persuratan, (b). dibagian persuratan akan di sortir seperti surat atau dokumen, barang kiriman sesuai dengan tujuan kota atau wilayah rute yang akan dikirim dan diserahkan kepada bagian antaran, (c). pada bagian antaran akan dilakukan proses pengiriman tersebut sesuai dengan tujuan atau rute yang dilakukan oleh pegawai kurir. Dari proses ini jasa pengiriman dituntut untuk tepat waktu, sehingga diharapkan dapat mempercepat proses pengiriman. Tetapi dari jasa pengiriman sendiri masih ada kesulitan dalam pendataan dan penentuan rute atau jarak, karena juga masih terjadi surat atau dokumen dan barang yang akan dikirim tersebut sudah dilalui dari rute atau wilayah sebelumnya walaupun sudah disortir ketujuan masing-masing.

Pencarian rute terpendek merupakan salah satu yang paling banyak dibahas. Dengan pencarian rute terpendek ini telah diterapkan di berbagai bidang untuk mengotimasi kinerja suatu sistem, baik dalam menentukan jarak tempuh agar mempercepat proses kiriman. Dalam pencarian rute terpendek, perhitungan dapat dilakukan dengan beberapa macam metode algoritma, salah satunya yaitu algoritma dijkstra.

Dari permasalahan diatas maka diperlukan sistem pencarian jalur terpendek untuk jasa pengiriman barang menggunakan algoritma dijkstra, algoritma yang cukup popular karena dapat menyelesaikan pencarian jalur terpendek dari satu ke semua simpul yang ada pada suatu graf bearah dengan bobot dan nilai tidak negatif.Dengan pembuatan aplikasi ini dapat membantu pegawai kurir PT. Pos Indonesia dalam menentukan jarak terpendek dan pendataan pengiriman tiap wilayah atau rute yang sudah ditentukan.

\subsection{Perumusan Masalah}

Berdasarkan latar belakang tersebut, maka rumusan masalah adalah sebagai berikut :

1. Bagaimana merancang dan membangun aplikasi berbasis mobile yang dapat membantu pegawai kurir PT. Pos Indonesia - Malang dalam pendataan alamat atau wilayah seputar kotaMalang sekaligus perhitungan untuk 
menentukan jarak atau rute terpendek barang kiriman?

2. Bagaimana merancang dan membangun aplikasi berbasis mobile yang dapat mengimpelementasikan algoritma dijkstra dalam pencarian jarak tempuh atau rute terpendek agar proses barang kiriman PT. Pos Indonesia - Malang lebih efisien dalam pendataan sesuai rute terpendek?

\subsection{Batasan Masalah}

Agar pembahasan yang lebih terarah, maka penulis mempunyai batasan masalah yaitu :

1. Aplikasi ini digunakan untuk membandingkan jarak terpendek (alamat) tiap kiriman surat atau barang yang akan di kirim pengantar dengan metode algoritma dijkstra.

2. Data yang diambil meliputi data mat atau daerah kiriman barang yang akan dikirim oleh pengantar kiriman.

\section{Landasan Teori}

\subsection{PT. Pos Indonesia}

Pos Indonesia telah beberapa kali mengalami perubahan status mulai dari Jawatan PTT (Post, Telegraph dan Telephone).Badan usaha yang dipimpin oleh seorang Kepala Jawatan ini operasinya tidak bersifat komersial dan fungsinya lebih diarahkan untuk mengadakan pelayanan publik.Perkembangan terus terjadi hingga statusnya menjadi Perusahaan Negara Pos dan Telekomunikasi (PN Postel). Mengamati perkembangan zaman dimana sektor pos dan telekomunikasi berkembang sangat pesat, maka pada tahun 1965 berganti menjadi Perusahaan Negara Pos dan Giro (PN Pos dan Giro), dan pada tahun 1978 berubah menjadi Perum Pos dan Giro yang sejak ini ditegaskan sebagai badan usaha tunggal dalam menyelenggarakan dinas pos dan giropos baik untuk hubungan dalam maupun luar negeri. Selama 17 tahun berstatus Perum, maka pada Juni 1995 berubah menjadi Perseroan Terbatas dengan nama PT Pos Indonesia (Persero).

Dengan berjalannya waktu, Pos Indonesia kini telah mampu menunjukkan kreatifitasnya dalam pengembangan bidang perposan Indonesia dengan memanfaatkan insfrastruktur jejaring yang dimilikinya yang mencapai sekitar 24 ribu titik layanan yang menjangkau 100 persen kota/kabupaten, hampir 100 persen kecamatan dan 42 persen kelurahan/desa, dan 940 lokasi transmigrasi terpencil di Indonesia. Seiring dengan perkembangan informasi, komunikasi dan teknologi, jejaring Pos Indonesia sudah memiliki 3.700 Kantorpos online, serta dilengkapi elektronic mobile pos di beberapa kota besar. Semua titik merupakan rantai yang terhubung satu sama lain secara solid \& terintegrasi. Sistem Kode Pos diciptakan untuk mempermudah processing kiriman pos dimana tiap jengkal daerah di Indonesia mampu diidentifikasi dengan akurat.

\subsection{Sistem Informasi Geografis (SIG)}

Merupakan sebuah sistem berbasis komputer yang digunakan untuk memasukkan, menyimpan, mengelola, dan menanalisis dan mengaktifkan kembali data yang mempunyai refrensi tempat untuk berbagai tujuan yang berkaitan dengan pemetaan dan perencanaan.

Sejarah sistem ini diperkenalkan di Indonesia pada tahun 1972, istilah Sistem Informasi Geografis diperkenalkan oleh General Assembly dari International Geographical Union di Ottawa Kanada pada tahun 1967. Sejak saat itu

Sistem Informasi Geografis berkembang dibeberapa benua terutama Benua Amerika, Benua Eropa, Benua Australia, Benua Asia.Perkembangan SIG menjadi pesat semenjak ditunjang oleh sumber daya yang bergerak di lingkungan akademis (kampus).

\subsection{Algoritma Dijkstra}

Algoritma Dijkstra ditemukan oleh Edsger.Wybe Dijkstra pada tahun 1959.Algoritma Dijkstra merupakan algoritma yang dapat memecahkan masalah pencarian jalur terpendek dari suatu graf pada setiap simpul yang bernilai tidak negatif dan termasuk dalam algoritma greedy, yaitu algoritma yang sering digunakan untuk memecahkan masalah yang berhubungan dengan suatu optimasi. Dalam pencarian jalur terpendeknya algoritma dijkstra bekerja dengan mencari bobot yang paling minimal dari suatu graf berbobot, jarak terpendek akan diperoleh dari dua atau lebih titik dari suatu graf dan nilai total yang didapat adalah yang bernilai paling kecil.

Langkah-langkah dalam menentukan lintasan terpendek pada algoritma Dijkstra yaitu:

1. Beri nilai bobot (jarak) untuk setiap titik ke titik lainnya, lalu set nilai 0 pada node awal dan nilai tak hingga terhadap node lain (yang belum terisi).

2. Set semua node "Belum terjamah" dan set node awal sebagai "Node keberangkatan".

3. Dari node keberangkatan, pertimbangkan node tetangga yang belum terjamah dan hitung jaraknya dari titik keberangkatan.

4. Setelah selesai menghitung setiap jarak terhadap node tetangga, tandai node yang telah terjamah sebagai "Node terjamah". Node terjamah tidak akan pernah di cek kembali, jarak yang disimpan adalah jarak terakhir dan yang paling minimal bobotnya.

5. Set "Node belum terjamah" dengan jarak terkecil (dari node keberangkatan) sebagai "Node Keberangkatan" selanjutnya dan lanjutkan dengan kembali ke step 3. 


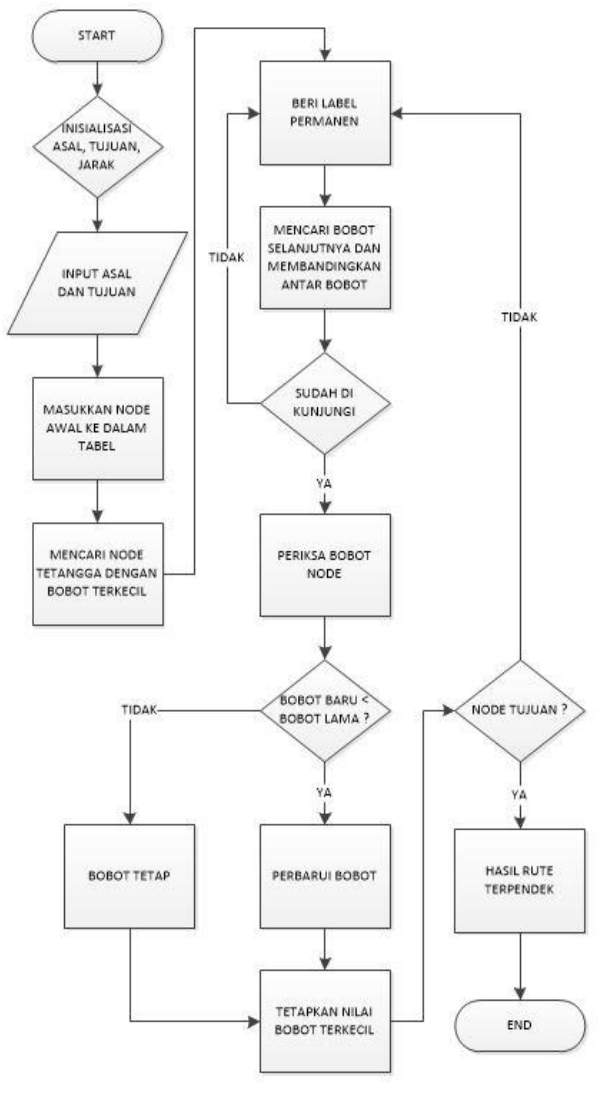

Gambar 1.Flowchart Metode Algoritma Dijkstra

\subsection{Google API}

Google API adalah kumpulan data suatu peta yang dapat membantu dalam menambahkan data peta di google. Dan dapat membantu dalam membuat aplikasi web atau seluler (android) yang menarik dengan platform pemetaan dari Google, termasuk dalam basis data citra satelit, street view, profil ketinggian, petunjuk arah, analisis yang basis data peta besar.

Dengan cakupan global yang paling akurat di dunia, dan komunitas pemetaan yang aktif memperbarui setiap kali pengguna dapat manfaat dari layanan yang ditingkatkan secara terus menerus.

\subsection{Android}

Android adalah sistem operasi untuk telepon seluler yang berbasis Linux.Android menyediakan platform terbuka bagi para pengembang buat menciptkan aplikasi mereka sendiri untuk digunakan oleh bermacam peranti bergerak.Awalnya, Google Inc. membeli Android Inc., pendatang baru yang membuat peranti lunak untuk ponsel. Kemudian untuk mengembangkan Android, dibentuklah Open Handset Alliance, konsorsium dari 34 perusahaan peranti keras, peranti lunak, dan telekomunikasi, termasuk Google, HTC, Intel, Motorola, Qualcomm, TMobile, dan Nvidia.

Pada saat perilisan perdana Android, 5 November 2007 Android bersama Open Handset Alliance menyatakan mendukung pengembangan standar terbuka pada perangkat selular. Di lain pihak, Google merilis kode-kode Android dibawah lisensi Apache, sebuah lisensi perangkat lunak dan standar terbuka perangkat seluler. Di dunia ini terdapat dua jenis distributor sistem operasi Andorid.Pertama yang mendapat dukungan penuh dari Google atau Google Mail Services (GMS) dan kedua adalah yang benar-benar bebas distribusinya tanpa dukungan langsung Google atau dikenal sebagai Open Handset Distribution (OHD).

\subsection{GPS}

Global Positioning System (GPS) merupakan sistem koordinat global yang dapat menentukan koordinat global yang dapat menentukan koordinat posisi benda dimana saja dibumi baik koordinat lintang, bujur, maupun ketinggiannya.Teknologi ini sudah menjadi standart untuk digunakan pada dunia pelayaran, penerbangan dan jalur darat didunia.

Sistem GPS dapat memberikan data koordinat global karena di dukung dari 24 satelit yang ada pada ketinggian orbit sekitar 11.000 mil diatas bumi. Teknologi GPS ini bebas dimanfaatkan oleh siapapun yang memiliki alat GPS receiver, ini adalah suatu alat yang dapat menerima sinyal satelit-satelit GPS untuk kemudian melakukan perhitungan koordinat posisi dirinya berdasarkan data yang ada.

Setiap satelit GPS dapat memancarkan sinyalsinyal gelombang mikro. GPS receiver menggunakan sinyal satelit yang diterima untuk melakukan triangulasi posisi dengan cara mengukur lama perjalanan waktu sinyal dikirim dari satelit, kemudian mengahlikannya dengan kecepatan cahaya untuk menentukan secara tepat beberapat jauh dirinya dari satelit.

GPS receiver akan terus menjaga dan mengunci sinyal satelit yang diperlukan untuk melakukan triangulasi secara bersama dengan pararel. Dengan sistem ini, informasi navigasi yang diterima akan selalu berkembang. GPS receiver juga akan terus menyari sinyal satelit sehingga mendapat 10 sampai 12 sinyal satelit sekaligus. Tambahan channel sinyal satelit ini diolah sehingga data koordinat yang diperoleh akan lebih terpercaya serta akurasinya lebih baik.

\section{Metodologi}

\subsection{Metode Pengambilan Data}

Metode pengambilan data di dalam penelitian ini, dilakukan dalam berbagai cara yaitu :

1. Observasi merupakan suatu proses yang komples, suatu proses yang tersusun dari 
berbagai proses biologis dan psikhologis. Dua diantara yang terpenting adalah proses-proses pengamatan dan ingatan. Melakukan pengumpulan data melalui pencatatan terhadap peristiwa yang di selidiki pada objek penelitian secara langsung yaitu dengan melalui bagian penting dalam pengambilan data yang di perlukan.

2. Wawancara merupakan pertemuan dua orang untuk bertukar informasi atau ide melalui tanya jawab, sehingga dapat dikontruksikan makna dalam suatu topik tersebut. Pengumpulan data melalui tatap muka dan tanya jawab secara langsung dengan narasumber atau sumber data yang penting berhubungan dengan penelitian. Analisis data adalah proses mencari dan menyusun secara sistematis data yang diperoleh dari hasil wawancara, catatan lapangan, dan bahan-bahan lain, sehingga mudah di pahami, dan temuan dapat diinformasikan kepada orang lain.

\subsection{Analisis}

Tahap ini dilakukan beberapa proses guna mengidentifikasi masalah yang terjadi serta mempelajari kebutuhan yang akan ada dalam pembangunan aplikasi pada penelitian ini. Hasil dari identifikasi masalah yang didapat terjadi karena proses pengiriman barang pada PT. Pos Indonesia sedikit mengalami kendala dalam proses pendataan barang yang sudah sampai kepada penerima selama proses perjalanan rute sebelumnya dan sesudahnya data yang diambil daerah sekitar kota Malang.

Setelah melakukan analisis yang ada pada proses pendataan dan perjalanan rute atau jalur pengiriman barang maka dibentuklah spesifikasi kebutuhan aplikasi yang akan digunakan untuk membantu untuk memecahkan permasalahan.

\subsection{Perancangan}

Perancangan sistem yang akan dilakukan pada penelitian ini terbagi menjadi beberapa proses, yaitu:

1. Perancangan basis data. Pada tahap ini dilakukan pembetukan skema dan diagram relasi berserta struktur tabel berdasarkan hasil analisis data yang dilakukan.

2. Perancangan arsitektual perangkat lunak atau aplikasi. Pada tahap ini dilakukan pembentukan struktur menu, antar muka perangkat lunak pesan dan jaringan sistematik yang digunakan didalam sistem.

3. Perancangan prosedural. Pada tahap ini dilakukan identifikasi alur proses yang akan diadopsi kedalam perangkat lunak atau aplikasi yang akan dibangun.

\subsection{Impelementasi}

Seteleah dilakukan analisis dan perancangan terhadap aplikasi yang akan dibangun maka langkah selanjutnya adalah mengimplementasikan hasil-hasil tersebut. Aplikasi ini dibangun menggunakan perangkat lunak dengan spesifikasi sebagai berikut:

1. Langkah awal dalam mengimplementasikan sistem adalah dengan basis data. Sesuai dengan hasil perancangan maka dibuatlah berupa tabel menggunakan DBMS MySql. Hasil dari impelementasi basis data dapat dilihat pada tabel .

2. Langkah berikutnya adalah mengimplementasikan antarmuka yang sesuai dengan hasil perancangan. Hasil implementasi antarmuka terbagi menjadi dua jenis, yaitu implementasi antarmuka admin dan implementasi antarmuka admin dapat dilihat pada tabel.

3. Hasil implementasi antarmuka yang sangat signifikan dalam pembangunan aplikasi pencarian rute terpendek jasa pengiriman barang PT. Pos Indonesia daerah Malang kota yang terdapat pada

\section{Analisis dan Perencanaan}

\subsection{Analisis Sistem}

Analisis sistem merupakan suatu penjabaran mengenai komponen - komponen penyusun sistem dalam penelitian ini baik perangkat lunak maupun perangkat keras.Serta gambaran umum sistem yang akan berjalan.

Proses yang terdapat pada penelitian ini terdiri dari dua proses yaitu proses traning yaitu meliputi pembuatan. Proses lainnya adalah proses testing dimana proses ini untuk mengindentifikasi hasil klasifikasi usia yang menggunakan metode Algoritma Dijkstra sebagai penyelesaian masalah dari klasifikasi jalur terpendek jasa pengiriman barang pada PT. Pos Indonesia - Malang.

\subsection{Analisis Perangkat Lunak}

Tahapan analisis ini di gunakan untuk mengatuhui kelebihan dan kekurangan aplikasi jarak terpendek yang dibuat. Adapum analisis yang dilakukan oleh perancang aplikasi meluputi beberapa komponen sebagai berikut :

1. Interface / tampilan system

Responden merasa tertarik dengan sistem ini karena dari segi tampilan antarmuka sistem user friendly, sehingga mudah dimengerti pengguna 
2. Informasi User

Fasilitas menu yang ada pada aplikasi dapat dipahami dan mencukupi kebutuhan pengguna.

\section{Kesimpulan}

Bedasarkan hasil penulisan dan pembahasan yang telah dilakukan, dapat disimpulkan bahwa :

1. Aplikasi jarak terpendek jasa pengiriman PT.Pos Indonesia - Malang adalah suatu aplikasi yang dapat menentukan jarak terdekat tiap wilayah kiriman dari tiap node.

2. Dengan adanya aplikasi penentuan jarak terpendek maka dapat memudahkan pegawai kurir dalam hal waktu dan jarak kiriman.

\section{Daftar Pustaka:}

Prahasta, E.,(2009): Sistem Informasi Geografis : Konsep-konsep Dasar (Perspektif Geodesi \& Geomatika), Bandung, Penerbit Informatika. 